\title{
KOMUNIKASI TRANS BUDAYA DALAM BIDANG KESEHATAN ANALISIS KASUS: IKLAN KONDOM DAN ATM KONDOM MASUK KAMPUS
}

\author{
Bani Eka Dartiningsih \\ (Dosen prodi Ilmu Komunikasi Universitas Trunojoyo Madura) \\ Basuki \\ (Dosen Ilmu Komunikasi Universitas Pembangunan Nasional “Veteran” Jogjakarta)
}

\begin{abstract}
Communication and culture reciprocally influence each other mutually. A culture where individuals are socialized, will affect the way they communicate. And how individuals that communicate, can change the culture that they have from time to time. Culture declined to patterns of behavior associated with certain groups of people, namely to "custom" or to "life principle" someone. Culture as a development towards balance. Condoms ATM case is a form of trans cultural communication where meaning contained in these products is that students are expected to behave safe (secure) way to have sex. Safe refers to healthy behaviors. The tool is not just a place to put a condom, but more contain message of healthy behaviors in sex. Despite the healthy word is reserved for people who are still categorized as deviant.
\end{abstract}

\section{ABSTRAK}

Komunikasi dan budaya secara timbal balik saling berpengaruh satu sama lain. Budaya dimana secara individu-individu disosialisasikan, akan berpengaruh terhadap cara mereka dalam berkomunikasi. Dan cara bagaimana individu-individu itu berkomunikasi, dapat mengubah budaya yang mereka miliki dari waktu ke waktu. Budaya menurun kepada pola perilaku yang diasosiasikan dengan kelompok orang tertentu, yaitu untuk "kebiasaan" atau untuk "prinsip hidup" seseorang. Budaya sebagai perkembangan menuju keseimbangan. Kasus ATM Kondom merupakan bentuk komunikasi trans budaya dimana makna yang terkandung dalam produk tersebut adalah bahwa mahasiswa diharapkan berperilaku safe (aman) dalam melakukan hubungan seks. Aman (safe) merujuk pada perilaku sehat. Alat tersebut bukan sekedar tempat menaruh kondom, tetapi lebih mengandung pesan perilaku sehat dalam berhubungan seks. Meskipun kata sehat tersebut dikhususkan bagi orang yang masih dikategorikan menyimpang.

Keywords: Komunikasi trans budaya, ATM kondom

\section{A. PENDAHULUAN}

\section{Analisis Situasi Tentang Perkembangan Seks bebas.}

Usia remaja adalah masa yang sarat dengan keinginan untuk melakukan kegiatankegiatan yang baru yang berdasarkan petualangan dan eksperimen sebagai refleksi dari gejolak muda para pelakunya. Remaja cenderung melakukan pencarian identitas dirinya dan biasanya cenderung melepaskan diri dari ikatan orang tuanya. Remaja akan lebih suka melakukan kegiatan pribadi dengan berkumpul bersama orang-orang sebayanya diluar dibandingkan bersama orangtuanya.

Pada masa remaja dikenal istilah pa- 
caran dalam berhubungan dengan lawan jenis. Pemahaman remaja tentang apa dan bagaimana itu pacaran dari waktu ke waktu semakin berkembang dan bervariasi. Berawal dari masa pacaran ini, sepasang remaja sering dipengaruhi oleh keinginan untuk selalu bertemu guna melepas rasa rindu sekaligus untuk saling memberi dan menerima perhatian dari pasangannya.

Kurangnya informasi tentang pendidikan seksual dari otang tua, ditambah adanya penyebaran informasi dan rangsangan seksual melalui media massa menjadikan remaja cenderung untuk mencoba dan meniru apa yang dilihat atau yang didengarnya dari media massa. Terjadinya perubahan-perubahan hormonal yang meningkatkan hasrat seksual (libido seksualitas) pada remaja yang membutuhkan penyaluran dalam bentuk tingkah laku seksual sehingga masa pacaran menjadi sarana untuk memuaskan dorongan seksual. Hal tersebut merupakan kegiatan perilaku seksual berisiko tinggi karena sebagian besar remaja tidak memiliki akses yang benar tentang informasi dan pelayanan kesehatan reproduksi yang dapat mengakibatkan kehamilan, aborsi, penyakit menular seksual, kekerasan seksual dan lain-lain.

Masalah seksualitas merupakan masalah yang pelik bagi remaja, karena masa remaja merupakan masa dimana seseorang dihadapkan pada berbagai tantangan dan masalah baik itu masalah perkembangan maupun lingkungan. Tantangan dan masalah ini akan berdampak pada perilaku remaja, khususnya perilaku seksualnya. Masalah ini menjadi bahan yang menarik untuk dibicarakan dan didiskusikan, karena sifatnya yang sensitif dan rawan menyangkut moral, etika, agama serta latar belakang sosial ekonomi. Hal ini tentunya menimbulkan kekhawatiran berbagai pihak baik orang tua, pengajar, pendidik maupun orang dewasa lainnya.

Kasus mengenai perilaku seksual pada remaja dari waktu ke waktu semakin mengkhawatirkan. Sementara di masyarakat terjadi pergeseran nilai-nilai moral yang semakin jauh sehingga masalah tersebut sepertinya sudah menjadi hal biasa, padahal penyimpangan perilaku seksual merupakan sesuatu yang harus dihindari oleh setiap individu. Salah satu contoh mengenai penyimpangan perilaku remaja, khususnya perilaku seksualnya yaitu sebuah penelitian yang dilakukan oleh Centra Mitra Remaja (CMR) Medan, Sumatra Utara, diperoleh ada lima tahapan yang sering dilakukan oleh remaja yaitu: dating, kissing, necking, petting dan coitus. Diperoleh data bahwa hampir $10 \%$ remaja sudah pernah melakukan hubungan seks. Penelitian PKBI DI Yogyakarta selama tahun 2001 menunjukkan data angka sebesar 722 kasus kehamilan tidak diinginkan pada remaja. Menurut Fakta HAM 2002 data PKBI Pusat menunjukkan 2,3 juta kasus aborsi setiap tahun dimana $15 \%$ diantaranya dilakukan oleh remaja (belum menikah). Faktor penyebab dari perilaku tersebut antara lain yaitu: semakin panjangnya usia remaja, informasi tentang seks yang terbatas, melemahnya nilai-nilai keyakinan serta lemahnya hubungan dengan orang tua (Yuwono, 2001).

Beberapa tahun (sekitar 12 tahun) yang lalu di Yogyakarta (khususnya) digemparkan oleh hasil penelitian Iip yang menyimpulkan bahwa hampir 90\% mahasiswi di Yogya sudah tidak virgin lagi. Tak pelak hasil penelitian tersebut mendapatkan kritikan yang mempertanyakan apakah metode yang digunakan sudah tepat. Terlepas dari apakah metode tersebut sudah benar atau tidak, penelitian tersebut memunculkan opini publik bahwa kehidupan seks bebas mahasiswa di Yogyakarta mengalami peningkatan yang 
signifikan (luar biasa). Hasil penelitian ini sempat mencoreng Yogyakarta yang punya julukan Kota Pendidikan. Orang tua menjadi khawatir ketika akan menyekolahkan anakanaknya ke Yogyakarta.

Yogyakarta memiliki daya tarik yang sangat besar bagi kalangan remaja untuk menempuh pendidikan yang lebih tinggi karena Yogyakarta telah dikenal sebagai pusat pendidikan sehingga populasi remaja di Yogyakarta akan tinggi. Populasi remaja akan menimbulkan masalah karena seperti telah dikemukakan perilaku seks remaja akhir-akhir ini mengarah kepada fenomena yang kian mengkhawatirkan dengan munculnya ketidak pedulian seksual di kalangan remaja yang menyangkut masalah kesehatan reproduksi.

Kurangnya informasi tentang pendidikan seks dari orangtua, ditambah adanya penyebaran informasi dan rangsangan seksual melalui media massa menjadikan remaja cenderung untuk mencoba dan meniru apa yang dilihat atau yang didengarnya dari media massa. Seringkali karena minimnya informsi yang benar mengenai pacaran unsur nafsu seksual menjadi dominan. Kehidupan seks bebas dikalangan remaja khususnya mahasiswa saat ini sudah dalam fase memprihatinkan. Salah satu bukti, mari kita dengarkan laporan tukang sedot toilet kampus. Hampir di kampus manapun, mereka melaporkan bahwa saluran toilet macet karena tersumbat begitu banyaknya kondom. Apa kesimpulannya? Banyak mahasiswa melakukan hubungan seks di kampus. Coba kita lihat kehidupan rumah kost-kostsan. Saat ini banyak bisnis kost yang dilakukan orang kaya, yaitu mereka membuat rumah yang didisain khusus untuk kost. Si pemilik tidak tinggal disitu. Keamanan dan kebersihan rumah diserahkan pada seorang tenaga. Apa jadinya, tidak sedikit mahasiswa/ mahasiswi masuk kamar teman yang lain jenis bahkan menginap. Apa daya seorang penjaga. Mari kita lihat kehidupan di jalan raya, mereka begitu mesranya berboncengan. Bahkan (maaf) seorang mahasiswa yang memakai jilbabpun larut dan begitu enjoynya berboncengan. Disain motor juga begitu memfasilitasi dan memanjakan dua insan lain jenis untuk bermesraan.

Fenomena yang mengejutkan lagi adalah dilaporkan bahwa seks bebas banyak dilakukan di rumah sendiri. Mengapa hal itu terjadi? Dewasa ini tidak banyak orang tua mampu mengontrol anak-anaknya. Orang tua sibuk bekerja. Berangkat pagi (bahkan jam 5 sudah berangkat, takut macet) dan pulang sore (bahkan malam). Siang hari anak-anak mereka tidak dalam pengawasan. Bagaimana dengan pembantu rumah tangga atau pekerja rumah tangga yang lain? Mereka tak berdaya (takut ancaman si anak). Akhirnya para pekerja ini bersikap masa bodoh dan pura-pura tidak tahu. Dalam situasi seperti ini, anak-anak begitu bebas melakukan seks bebas di rumah sendiri di siang hari. Kehidupan anak-anak sekarang begitu dimanjakan (semua kebutuhan terpenuhi), tetapi minus pengawasan. Bahkan orang tua saat ini merasa malu jika anaknya belum punya pacar. Ada banyak orang tua yang bangga jika anaknya bisa dapat pacar anak gedongan. Dan tidak banyak orang tua yang menasehati anaknya untuk tidak dekat-dekat dengan teman lain jenis. Inilah kondisi yang menyebabkan semakin terbukanya remaja dan mahasiswa melakukan seks bebas.

Realita seks bebas dikalangan mahasiswa bisa digambarkan seperti gunung. Yang kelihatan dipermukaan tidak seberapa, tetapi kalau kita cermati dengan seksama kondisinya sudah sangat amat memprihatinkan. Apa yang bisa dilakukan? Sulit, karena tidak ada (orang tua sekalipun) yang mampu memelototi anaknya dari bangun tidur sampai bangu tidur lagi. 
Bagaimana pendidikan? Nampaknya hanya formalitas. Faktor lingkungan dan teknologi semakin mendukung perilaku seks bebas. Bagaimana dengan agama. Inilah benteng terakhir yang bisa mencegah. Tetapi agama juga sekedar formalitas menjalankan ritual. Apa lacur, begitu selesai menjalankan ritual, sesuatu yang memanjakan dunia kita kejar tanpa menghiraukan hukum agama (haram dan halal).

Kerentanan remaja terhadap sekian resiko seksualitas sangat memprihatinkan banyak pihak. Ketidakakuratan informasi seksualitas yang diperoleh, mendekatkan remaja pada penyakit menular seksual dan HIV/ AIDS. Para remaja membutuhkan informasi seksualitas yang benar, baik remaja laki-laki dan perempuan. Penderita penyakit menular seks terus meningkat. Tampaknya orang tidak takut lagi tentang penyakit yang belum ada obatnya seperti HIV/AIDS. Meskipun penularannya tidak hanya melalui hubungan intim saja, tetapi aktifitas ini termasuk yang potensi dalam penularannya. Bahkan dapat dikategorikan yang pertama kali.

Melihat pergaulan anak-anak muda kita calon pemimpin bangsa, pada usia yang sangat produktif generasi muda kita terkena dampak negatif dari perkembangan teknologi yang maju pesat saat ini. Seperti teknologi internet yang sudah sangat meluas sekali di masyarakat kita, banyak sekali situs-situs porno yang bisa diakses melalui internet oleh anak-anak kita, dvd porno yang sangat mudah diperoleh di penjual-penjual dvd. Hal ini sangat membuat khawatir akan perkembangan mental dan pikirian remaja. Menurut data yayasan kapete usia muda yang terjangkit HIV/AIDS di Indonesia sangat tinggi. Penularan HIV/AIDS pada usia muda banyak terjadi melalui hubungan sexs.

\section{B. PEMBahasan}

\section{Iklan Kondom dan ATM Kondom di Kampus}

Ada beberapa hal yang penting dalam setiap aktivitas "iklan kesehatan", yakni memasarkan informasi tentang barang atau jasa mengenai ikhwal kesehatan. Para pengiklan selalu percaya bahwa berkomunikasi efektif dengan audiens merupakan bagian terpenting dari setiap pemasangan iklan. Untuk terus menekan angka penderita HIV/ AIDS pemerintah melakukan kampanye penggunaan kondom bagi orang-orang yang gemar melakukan seks bebas. Itu dilakukan baik menggunakan media above the line maupun below the line. Isi iklan adalah kondom bukan alat kontrasepsi bagi yang akan mengatur jumlah dan jarak kalahiran, tetapi justru bagi orang yang suka melakukan seks bebas dengan berganti-ganti pasangan. Kita cermati tagline iklan tersebut "mau aman pakai kondom". Anak-anak muda pun begitu antusias menyambutnya dengan memasang stiker merek kondom ( durex, fiesta) di motor, mobil, pintu kost mereka.

Tempat penjualan kondom tidak hanya di apotik atau puskesmas saja. Tempat-tempat yang biasa disinggahi mahasiswa sepaerti Alfamart, Indomart juga menyediakan. Siapa pembelinya? Menurut pengakuan salah satu penjaga, kebanyakan anak-anak remaja yang kelihatannya belum menikah. Alfamart, Indomart adalah swalayan untuk pemenuhan kebutuhan sehari hari. Dengan kata lain, jika kondom dijual disitu, berarti kondom merupakan barang kebutuhan sehari-hari.

Tampak keberadaan kondom di tempattempat umum sudah menjadi tuntutan masyarakat. Suatu ide yang cukup mengundang perhatian publik sekitar 4 tahun lalu adalah diperlukannya ATM kondom masuk 
kampus. Sebagian orang menganggap itu ide gila. Kenapa mahasiswa yang sedang belajar disuguhi kondom di dekatnya. Apakah ini bukan berarti melembagakan apa yang diharamkan menjadi halal. Ataukah seke-dar membawa ke ranah yang abu-abu (meragukan). Pertanyaan menarik adalah kenapa ide itu muncul? Jawabannya adalah itu menghindari/mencegah penularan HIV/ AIDS sebagai ekses dari perilaku seks bebas. Menurutnya mencegah perilaku seks bebas ibarat membendung air bah (pekerjaan yang mustahil). Maka jalan yang ditempuh adalah mencegah efek dari perilaku bebas tersebut. Solusinya adalah menyediakan kondom di berbagai tempat yang mudah diakses oleh siapapun. Berkait ATM kondom di kampus tersebut berarti menyediakan fasilitas mudah dan cepat bagi mereka yang suka melakukan seks bebas.

Adakah kampus yang mengakomodir ide gila tersebut. Tidak tanggung-tangung Rektor Universitas Kristen Duta Wacana (UKDW) menyetujui dan merealisasi ATM kondom dibangun di kampusnya. Ide ATM Kondom masuk kampus jadi kenyataan. Apa reaksi yang muncul? Dapat dikatakan tidak ada. Tidak ada media yang mencoba menanggapi fenomena tersebut. Dengan demikian dapat dikatakan bahwa perilaku seks bebas sudah tidak dipersoalkan lagi. Demikian halnya, hampir tidak ada mengomentari iklan kondom yang slogannya jelas-jelas menyetujui perilaku seks bebas tersebut (termasuk dalam hal ini tokohtokoh agama ).

\section{Seks dan Kebudayaan}

Perkembangan teknologi membuat seks tidak dianggap sakral lagi. Penemuan alat kontrasepsi oleh AS kemudian memicu revolusi seks di tahun 1960-an. Paradigma pun berubah. Seks dianggap sebagai hal yang biasa-biasa saja. Akibatnya pergaulan seks bebas punmarak. Imbasnya juga dirasakan di Indonesia. Perubahan pandangan terhadap seksualitas terjadi sejak awal tahun 1980an. Hal ini juga mengakibatkan perubahan dalam perilaku seksual termasuk di kalangan remaja. Banyak faktor yang menjadi penyebab terjadinya perubahan pandangan dan perilaku seksual tersebut. Contohnya, perkembangan iptek seperti internet, semakin longgarnya pengawasan dan perhatian orangtua dan keluarga akibat kesibukan, pola pergaulan yang semakin bebas dan lepas (sementara orangtua mengizinkan), lingkungan yang makin permisif, semakin banyak rangsangan seksual yang berasal dari luar dan fasilitas yang mendukung.

Kesiapan mental akan memberikan pendidikan seks pada remaja sangat perlu dimiliki orang tua, tetapi kenyataannya banyak orang tua yang belum siap memberikan informasi seksualitas kepada anak-anak remajanya. Orangtua yang benar-benar tidak paham mengenai pendidikas seks akan lebih kuat penolakannya disbanding yang sudah sadar pentingnya permasalahan kesehatan reproduksi dan perkembangan seksual remaja. Kendala budaya, pengetahuan serta beban psikologis seringkali menjadi hambatan bagi orang tua dalam berkomunikasi tentang masalah seksual yang sehat dan bertanggung jawab dengan para remaja. Namun satu hal yang harus senantiasa diingat oleh orang tua bahwa peran mereka dibutuhkan oleh para remaja. Jika orang tua tidak mengambil peran tersebut maka dunia luar yang akan mengambilnya. Oleh karenanya orangtua harus dengan berbagai cara berupaya untuk membuka komunikasi tersebut. Orangtua tidak bisa menghindari anak-anaknya dari pengetahuan akan seks. Mereka akan mencari 
sendiri atau memperoleh informasi dari lingkungan dimana mereka bergaul.

Kebutuhan sekspadamanusiamerupakan fitrah yang diberikan oleh Allah SWT. Tidak ada manusia terlahir tanpa nafsu tersebut. Patut disyukuri karena itu menunjukkan identitas kita sebagai manusia. Dengan anugerah ini manusia bisa mengenal rasa cinta kasih, saling menyayangi, dan lebih dari itu manusia bisa melanggenggkan keturunannnya. Dalam hal ini, manusia dengan hewan sama yaitu sama sama dibekali kebutuhan seks.

Lalu apa yang membedakan manusia dengan hewan. Manusia oleh Sang Pencipta dibekali akal dan hati nurani. Maka dalam mewujudkan kebutuhan seks tidak akan sama dengan hewan. Dengan akal dan hati maka banyak aturan-aturan yang harus ditaati manusia agar tidak mengganggu manusia yang lain. Bahkan aturan-aturan itu tidak saja yang dibuat dan dilembagakan sendiri oleh manusia tetapi Allah SWT pun langsung memberi aturan-aturan itu. Pada intinya manusia dilarang berzina. Hubungan seks merupakan aktifitas yang disucikan oleh Sang Khalik. Manusia disuruh berhati-hati dan tidak diijinkan mengumbar nafsunya sembarangan.

Apa yang boleh dan apa yang tidak boleh itu akhirnya dilembagakan dalam peraturan baik tertulis maupun tak tak tertulis. Itulah akhirnya kebutuhan seks menjadi bagian yang pelik dari kehidupan manusia. Dengan kata lain perilaku seks sudah menjadi budaya manusia. Budaya tersebut meliputi norma/nilai, adat, pakaian, perilaku dan sebagainya. Ada wanita yang boleh/tidak boleh dinikahi. Hubungan seks hanya boleh dilakukan jika sudah menikah. Untuk menikah persyaratannya banyak dan jika harus dipenuhi. Menikah membutuhkan pemikiran dan pengurbanan. Karena menikah pada prinsipnya mengubah dari sesuatu yang diharamkan menjadi di- halalkan bahkan diwajibkan dan bernilai ibadah. Budaya adalah tatanan pengetahuan, pengalaman, kepercayaan, nilai, sikap makna, agama, waktu, peranan, yang diperoleh sekelompok besar dari waktu ke waktu melalui proses belajar.

Dewasa ini perilaku yang sangat disucikan dan disakralkan tersebut nampaknya mulai mengalami kelonggaran. Hubungan intim merupakan hiburan yang kapanpun, dimanapun boleh dilakukan meskipun tanpa ikatan apapun. Menurut pengamatn penulis, terjadi revolusi yang begitu cepat dari yang dilaharamkan menjadi dihalalkan. Dari yang harus melalui proses rumit dan panjang menjadi sessuatu yang bebas. Dari yang tujuannya ibadah (meneruskan garis keturunan) sesuai agama menjadi hiburan.

Berdasarkan pengamatan, 15 tahun yang lalu orang masih hati-hati terlalu dekat dengan orang yang bukan muhkrimnya. Apalagi naik motor berduaan (rasanya masih tabu). Tetapi sekarang sudah merupakan kebutuhan sehari-hari. Dan masih banyak lagi perilaku yang dulu amat ketat tetapi sekarang begitu longgar. Satu hal yang penting adalah orang sudah memaklumi hal ini sebagai konsekuensi perkembangan jaman. Padahal yang sejatinya kehidupan manusia justru mengalami kemunduran jauh ke belakang.

Masyarakat sudah begitu tak peduli dengan fenomena tersebut. Buktinya masyarakat tidak memprotes iklan yang keliru, masyarakat tidak memprotes ATM kondom. Saat itu tumbuh subur bisnis pengguguran kandungan. Bahkan bisnis ini terang-terangan pasang iklan di berbagai media. Contoh, perhatikan di kebanyakkan traffic light banyak dipasang iklan dengan tag line "anda terlambat datang bulan hubungi no $\mathrm{xxxxxxxx"}$

Satu pertanyaan penting yang perlu dijawab adalah akankah perilaku seks bebas 
yang diamini masyarakat pada akhirnya menjadi bagian kehidupan manusia dan akhirnya melahirkan budaya baru. Jawabnya, bisa. Kenapa demikian? Banyak kejadian yang mengarah kesana, antara lain :

1. Masyarakat hampir tidak melakukan upaya mencegah perilaku seks bebas. Masyarakat dan pemerintah sibuk melakukan pencegahan dari ekses yang ditimbulkan perilaku tersebut. Pendidikan seks di rumah, kampus sangat lemah (bahkan dianggap tabu).

2. Pengawasan orang tua terhadap anak sangat lemah. Anak dicukupi kebutuhan jasmaninya saja.

3. Banyak orang memprotes undang-undang pornografi dan pornoaksi

4. Menikah atau tidak menikah adalah dikatakan hak asasi manusia.

5. Tidak ada sangsi hukum yang tegas bagi mereka yang melakukan hubungan seks secara bebas.

6. Bahkan di negara-negara tertentu lebih gila lagi. Bukan hanya seks bebas, perilaku menyimpang pun sudah diakomodir dengan undang-undang yaitu pengakuan terhadap pasangan sesama jenis. Termasuk pengaturan adopsi anak bagi mereka.

Penulis mencoba melakukan focus group discussion dengan 6 mahasiswa. Tema diskusi adalaha seputar iklan kondom dan ATM kondom di kampus. Mereka tidak menolak keberadaan dua fenomena tersebut. Mereka menilai tujuannya jelas dan baik. Tetapi ia tidak setuju dengan dihalalkannnya atau paling tidak disetujuinya perilaku seks bebas. Apakah mahasiswa akan memanfaatkan sarana tersebut. Jawabnya, tidak. Kenapa? Malu! Dari jawaban terakhir ini sebenarnya masih ada penilaian bahwa perilaku tersebut masih tidak disetujui oleh masyrakat secara terbuka. Tetapi ke depan orang melakukan kumpul kebo tidak akan malu lagi. Seperti di negara-negara tertentu menikah lawan jenis sekalipun tidak malu. Padahal secara agama manapun dilarang. Tetapi pemerintahnya yang tak berdaya ketika dipojokkan dengan masalah HAM dalam urusan menikah. Sekarang banyak muncul subkelompok menyimpang (deviant subgroup) yang terus berusaha memperoleh legitimasi masyarakat.

\section{KESIMPULAN}

\section{Komunikasi Trans Budaya Dalam Kesehatan.}

Komunikasi trans budaya berbeda dengan komunikasi antar budaya. Komunikasi antar budaya adalah komunikasi yang terjadi antar etnik yang berbeda. Komunikasi antar budaya terbatas bagaimana seseorang bekomunikasi dengan orang lain yang secara etnik berbeda. Komunikasi trans budaya tidak hanya mengkaji manusia dengan manuisa yang sedang berkomunikasi (lebih dari itu). Sebagai contoh model rumah merupakan pesan yang harus dimaknai dalam komunikasi trans budaya. Semua hasil budaya manusia yang berupa artefak mengandung pesan tersendiri yang harus dimaknai.

Komunikasi bidang kesehatan merupakan bentuk komunikasi trans budaya. Mengapa? Telah terjadi perbedaan nilai antar generasi ke generasi. Generasi tua selalu ketat tentang perilaku seks yang boleh dan tidak boleh dilakukan. Generasi muda cenderung longgar dalam memahami perilaku seks. Bukan pekerjaan mudah untuk sosialisasi dan internalisasi tentang nilai-nilai sakral seks. Banyak orang (terutama orang tua) mengalami gegar budaya, yaitu orang merasa asing ditengah-tengah budaya yang dianut. Tidak sedikit orang yang justru mendapat 
cemoohan ketika mengingatkan seseorang untuk tidak melakukan seks bebas. Pendidikan seks di sekolah-sekolah formal dianggap tabu. Sebagian masih menilai, apakah sesuatu yang dirahasiakan dapat dipelajari bersama-sama.

Kasus ATM Kondom merupakan bentuk komunikasi trans budaya dimana makna yang terkandung dalam produk tersebut adalah bahwa mahasiswa diharapkan berperilaku safe (aman) dalam melakukan hubungan seks. Aman (safe) merujuk pada perilaku sehat. Alat tersebut bukan sekedar tempat menaruh kondom, tetapi lebih mengadung pesan perilaku sehat dalam berhubungan seks. Meskipun kata sehat tersebut dikhususkan bagi orang yang masih dikategorikan menyimpang. Agar komunikasi trans budaya tersebut tidak semakin melegalkan perilaku menyimpang para mahasiswa maka perlu dilakukan penyampaian pesan komunikasi trans budaya yang mengajak mahasiswa atau siapa saja tidak melakukan seks bebas. Kampanye ini harus dilakukan dengan bentuk komunikasi trans budaya. Tidak hanya dilakukan di dalam pengajian-pengajian saja. Perlu dibuat simbol/ pesan yang membuat orang jadi tidak berani melakukan seks bebas. Saya belum pernah menemukan slogan yang melarang perilaku seks bebas, misal: katakan "tidak" pada free seks.

\section{DAFTAR PUSTAKA}

Alo Liliwery, A. 2007, Dasar-Dasar Komunikasi Kesehatan. Yogyakarta : PT. Pustaka Pelajar

Basri, H. 1994. Remaja Berkualitas. Yogyakarta : Pustaka Pelajar.

Hanafi, Abdillah, 1998, Memahami Komunikasi Antar Manusia, Surabaya.Penerbit Usaha Nasional.

Poerwandari, E. Kristi,2001.Pendekatan kualitatif untuk Penelitian Perilaku Manusia. Jakarta: Lembaga Pengembangan Sarana Pengukuran dan Pendidikan Psikologi (LPSP3)UI

Rakhmat,Jalaluddin.2005.Psikologi Komunikasi. Bandung: PT. Remaja Rosdakarya

Sarwono, Sarlito W. 2002.Psikologi Remaja: PT. Remaja Rosdakarya 